\title{
Seed-Borne Fungi of Sunflower (Helianthus annuus L.) and their Impact on Oil Quality
}

\author{
El-Wakil, D. A. \\ Agricultural Research Center, Plant Pathology Research Institute, Egypt. \\ Kingdom of Saudi Arabia, Jazan University, College of Science, Biology Department.
}

\begin{abstract}
The deteriorating in sunflower oil due to seed-borne fungi is of a great importance. In the present study ten seed-borne fungi were isolated from abnormal sunflower seeds collected from different locations in Egypt i.e. Aspergillus flavus, A. niger, Alternaria alternata, Curvularia lunata ,Fusarium moniliforme, $F$. oxysporum, F . semitectum, Penicillum digitatum, Stemphylium sp., and Trichoderma spp. A noticeable variation was recorded in sunflower oil samples such as chemical properties i.e. saponification number, fatty acid value, iodine number, peroxide value also, physical properties i.e. moisture content, gravity, odor absorbent, absorbance (470nm) and oil colour, these differences are due to the secondary metabolites produced by storage fungi. Some of the tested fungi gave a remarkable differences in both of absorbance and odor i.e. with F. semitectum and Stemphylium sp. treatments.
\end{abstract}

Keywords: Sunflower seed-borne fungi, oil deterioration, chemical and physical properties, biochemical changes of oil samples.

\section{Introduction:}

Sunflower (Helianthus annuus L.), considered a commercial oil crop all over the world. The crop is widely cultivated in Egypt and all over the world. Sunflower is particularly used for production of edible oil as well as for seed consumption [1], [2] and [3]. Seeds used for cultivation of the crop are mostly hybrids in Egypt. However, during the last years some attempts were made to produce sunflower hybrids and new genotypes adapted to the climate of different regions in Egypt and to be higher in oil production. Sunflower is one of the most important producers of oil among different oil crops all over the world. Fats and oils are important ingredients of human food. Sunflower seeds contain $40-50 \%$ oil and $23 \%$ protein and constitute an excellent source of unsaturated fats, crude protein and fibers and important nutrients like many vitamins .Sunflower is affected by a large number of diseases caused by many fungi, and other phytopathogenic microorganisms. Most of sunflower fungal species are reported to be seed-borne [4]. Thirteen isolated phytopathogenic fungal species were isolated from different stored sunflower varieties .Externally seed-borne mycoflora are saprophytes but a few were parasites also occur along with them. The internal seed mycoflora is composed of parasites as well as saprophytic organisms. The presence of 13 species in unsterilized and 12 species from sterilized sunflower seeds was detected and reported by [5]. During storage conditions sunflower seeds are exposed to various infections by microorganisms like fungi which may lead to various damage including reducing yields of seed in both qualitatively and quantitatively, besides these decreases in germination percentage, mycotoxin production and total decay has been observed [4],[5].

The present study was carried out to survey seed-borne mycoflora of sunflower, testing the effect of some storage fungi on sunflower oil quality and to investigate some of the physical and the chemical properties of deteriorating oil.

\section{Materials and Methods:}

\section{Source of seed samples:}

Ten sunflowers (Helianthus annuиs L.); seed samples were collected from different locations in Assiut governorate in Egypt the obtained samples were brought to the laboratory and kept at room temperature for the present study as shown in Fig.(1).

\section{Isolation of sunflower seed- borne fungi:}

A subsample of 100 abnormal sunflower seeds from each sample was surface sterilized in $2.0 \%$ Clorox solution for one minute, and washed several times with sterilized water. The surface sterilized seeds were then blotted between two dry sterilized filter paper. Seed- borne fungi were determined by the standard PDA method [6] and [7] .Twenty five sterilized sunflower seeds of each sample were randomly selected and plated on Petri dishes, each was replicated 4 times; plates were incubated for 12-hour duration of darkness and light at $20 \pm 2 \mathrm{C}^{0}$ for 7 days .After incubation period each colony examined macroscopically or microscopically for identification the genus or species level according to [6] and [7]. 


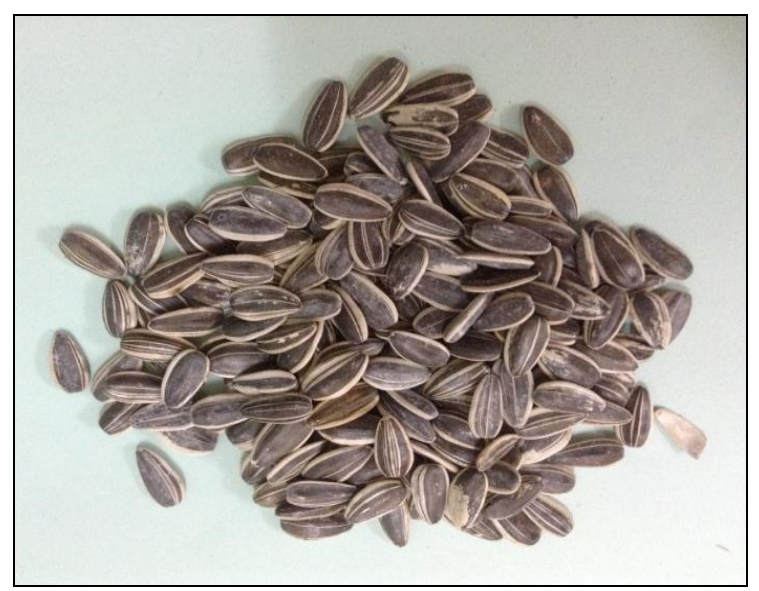

Fig.(1).Showing a working sample of sunflower seeds submitted for isolation with the standard PDA method.

\section{Properties of the sunflower oil samples:}

The refined sunflower oil samples were collected from the oil producers in sterilized tubes. These samples were brought into the laboratory. Spores and mycelium fragments of ten fungi each fungus individually which previously isolated from abnormal sunflower seeds were inoculated in a conical flask containing $100 \mathrm{ml}$ oil each of sunflower oil samples (10 samples) under aseptic conditions. After thirty days later, oil was filtered and these oil samples were used for the estimation of both chemical and physical properties under sterilized conditions according the described method by [8].

\section{Physical properties:}

\section{1- Determination of moisture content from oil:}

The moisture content was estimated [9]. About $1 \mathrm{ml}$ of oil was taken in a moisture dish provided with tight filling slip over cover. The dish was dried previously, cooled in the desiccators (containing an efficient desiccant) and weighed. The dish was placed in the air oven for approximately two hours at $105 \mathrm{C}^{0}$. The dish was removed from the oven, cooled in the desiccators at room temperature and weighed. This procedure was repeated but the dish kept in the oven only for half an hour each time until the difference between the two successive weighing does not exceed one milligram. The moisture content was calculated by following formula:

$$
\text { Moisture } \%=\frac{100[\mathrm{M} 1-\mathrm{M} 2]}{-\mathrm{MI}-\mathrm{M}}
$$

M1 = mass in gm of the dish with the material before drying process.

$\mathrm{M} 2=$ mass in $\mathrm{gm}$ of the dish with the material after drying process.

$\mathrm{M}=$ mass in gm of the empty dish.

\section{2- Determination of oil colour:}

Colour of deteriorated oil was determined by observing the grade of the yellow colour as yellow, bright yellow, dark yellow, light yellow and pale yellow and so on.

\section{3- Determination of specific gravity:}

The specific gravity was estimated [8], [9]. The weight of dry specific gravity bottle was taken (B). The dry specific gravity bottle filled with the $5 \mathrm{ml}$ of the sample. After fixing the stopper, weight was taken (A). The weight of the specific gravity bottle containing $5 \mathrm{ml}$ of distilled water was taken (C). The specific gravity was calculated by the formula:

$$
\text { Specific gravity at } 30 \mathrm{C}^{0}=\quad \begin{gathered}
\text { A } \\
--\mathrm{B}
\end{gathered}
$$

$\mathrm{A}=$ Weight in gm of specific gravity bottle with oil at $30 \mathrm{C}^{0}$. 
$\mathrm{B}=$ Weight in gm of specific gravity bottle at $30 \mathrm{C}^{0}$.

$\mathrm{C}=$ Weight in gm of specific gravity bottle with distilled water at $30 \mathrm{C}^{0}$

\section{4- Determination odor of deteriorated oil:}

For this test the odor of the deteriorated seed oil was determined by just smelling the sample under the study to detect its case in relation to the oil in check treatment.

\section{5-Absorbance of deteriorated oil:}

The O.D. at 420nm absorbance of deteriorated oil was recorded to study the effect of storage fungi on the tested oil samples infected with target fungal individually.

\section{Chemical parameters:}

1- Determination of peroxide value:

The peroxide value of sunflower oil was calculated; Fig. (2). One gm of sample of oil was taken in a test tube $20 \mathrm{ml}$ acetic acid / chloroform solution (2:3 volumes) and $1 \mathrm{~g}$ powdered potassium iodide was added. The tube was placed in boiling water bath until liquid boil vigorously. The contents were quickly transferred to the flask containing $20 \mathrm{ml}$ of $5 \% \mathrm{KI}$ solution. The tube was washed quickly with $25 \mathrm{ml}$ Distilled water each time and collected in a conical flask, yellow colour was appeared. This was then titrated with $0.1 \mathrm{~N}$ sodium thiosulphate solution with constant and vigorous shaking. The titration was continued till the yellow colour almost disappeared $0.5 \mathrm{ml}$ of starch solution was added and continued titration till the blue colour just disappeared. A blank determination of reagent was conducted. Peroxide value was calculated by the formula:

\section{[S-B] X N X100}

Peroxide value $=$

$$
\text { Sample weight }
$$

$\mathrm{B}=$ Titration of blank test $\mathrm{ml}$.

$\mathrm{S}=$ Titration of sample $\mathrm{ml}$.

$\mathrm{N}=$ Normality of sodium thiosulphate solution

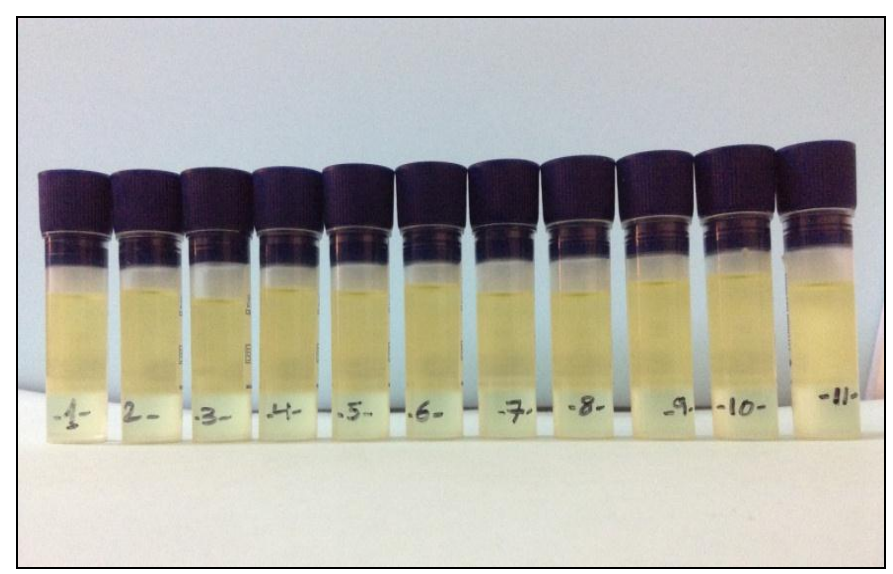

Fig.(2). Showing a subsamples of sunflower oil used in the study where, no.11 is check treatment.

\section{2- Determination of iodine value:}

The iodine value was determined according to the titrometric method as reported by [8]. $2 \mathrm{~g}$ of oil sample was weighed into a dry glass bottle of $250 \mathrm{ml}$ capacity and $10 \mathrm{ml}$ of carbon tetrachloride was added to the oil. U-boat $20 \mathrm{ml}$ of solution (Mix $1.5 \%$ of Iodine monochloride and $97 \%$ of Glacial acetic acid) was then added and allowed to stand in the dark for $30 \mathrm{~min}$. $15 \mathrm{ml}$ of $(10 \%)$ potassium iodide and $100 \mathrm{ml}$ of water was added and then titrated with $0.1 \mathrm{M}$ sodium thiosulphate solution using starch as indicator just before the end point. A blank was also prepared alongside the oil samples. Iodine value was calculated from the formula:

$$
\text { Iodine value }=\frac{\left(\mathrm{V}_{2}-\mathrm{V}_{1}\right) \times 1.269}{\text { Sample Weight }(\mathrm{g})}
$$

Where: V1=titer value for sample 
$\mathrm{V} 2=$ titer value for blank

$\mathrm{S}=$ sample weight in $(\mathrm{g})$

\section{3- Determination of Saponification value:}

The Saponification value was determined according to the titer metric method [9]. $2 \mathrm{~g}$ of oil sample was weighed into a conical flask and $25 \mathrm{ml}$ of alcoholic potassium hydroxide was added. The solution was heated in boiling water for 1 hour. $1 \mathrm{ml}$ of $1 \%$ phenolphthalein was added and titrated with $0.5 \mathrm{~N} \mathrm{Hcl}$. A blank was prepared alongside the oil samples the value was calculated by the formula:

$$
\begin{array}{ll}
\text { Saponification no. }= & 56.1 \mathrm{X}(\mathrm{B}-\mathrm{S}) \mathrm{X} \mathrm{N} \\
\text { Sample Weight }(\mathrm{g})
\end{array}
$$

Where:

$\mathrm{B}=$ Volume in $\mathrm{ml}$ of $0.5 \mathrm{~N}$ Hydrochloric acid.

$\mathrm{S}=$ Volume in $\mathrm{ml}$ of 0.5 Hydrochloric acid.

$\mathrm{N}=$ Normality of Hydrochloric acid.

$\mathrm{W}=$ Weight of oil in gm

\section{4-Determination of free fatty acid content:}

Free fatty acid content was estimated by the method recommended [9]. $2 \mathrm{ml}$ of oil was dissolved in $50 \mathrm{ml}$ of neutral solvent in $250 \mathrm{ml}$ conical flask. Few drops of phenolphthalein indicator were added and titrated against $0.1 \mathrm{~N}$ potassium hydroxide. Constant shaking was done until pink colour was persisted for fifteen seconds and acid value was calculated by the formula:

Acid value $=$

Titer value X Normality of $\mathrm{KOH} \mathrm{X} 56.1$

$$
\text { Weight of sample (g) }
$$

\section{Results and Discussion:}

The data shown in Table (1) indicate that out of ten samples of sunflower seeds (Helianthus annuus L.), ten seed-borne fungi were detected i.e. Aspergillus flavus, Aspergillus niger,Alternaria alternata, Curvularia lunata, Fusarium moniliforme, F.oxysporum, F. semitectum,Penicillim digitatum,Stemphylium sp.and Trichoderma spp.; the most dominant fungus was Aspergillus niger with all of the examined samples followed by Aspergillus flavus and Fusarium spp. The obtained data are similar to those reported by [1],[2] and [3], they stated that seed mycoflora are of a great importance for seed deterioration and consequently lead to seed losses and this may be as a result of the secretion of mycotoxin and fungal secondary metabolites which

\begin{tabular}{|c|c|c|c|c|c|c|c|c|c|c|}
\hline Isolated fungi & $* \mathbf{S}-1$ & S-2 & S-3 & S-4 & S-5 & S-6 & S-7 & S-8 & S-9 & S-10 \\
\hline Aspergillus flavus & 12.0 & 10.0 & 12.0 & 16.0 & 18.0 & 17.0 & 19.0 & 19.0 & 10.0 & 5.0 \\
\hline Aspergillus niger & 24.0 & 13.0 & 22.0 & 7.0 & 16.0 & 18.0 & 16.0 & 15.0 & 17.0 & 17.0 \\
\hline Alternaria alternata & 30.0 & 21.0 & 17.0 & 18.0 & 0.0 & 0.0 & 13.0 & 21.0 & 18.0 & 15.0 \\
\hline Curvularia lunata & 5.0 & 10.0 & 18.0 & 24.0 & 17.0 & 2.0 & 22.0 & 11.0 & 19.0 & 12.0 \\
\hline Fusarium moniliforme & 7.0 & 19.0 & 2.0 & 0.0 & 0.0 & 15.0 & 12.0 & 13.0 & 10.0 & 14.0 \\
\hline Fusarium oxysporum & 4.0 & 0.0 & 10.0 & 12.0 & 3.0 & 2.0 & 16.0 & 17.0 & 0.0 & 18.0 \\
\hline Fusarium semitectum & 0.0 & 8.0 & 11.0 & 0.0 & 11.0 & 11.0 & 0.0 & 0.0 & 17.0 & 0.0 \\
\hline Penicillum digitatum & 7.0 & 11.0 & 0.0 & 5.0 & 18.0 & 17.0 & 0.0 & 4.0 & 0.0 & 11.0 \\
\hline Stemphylium sp. & 0.0 & 5.0 & 0.0 & 10.0 & 0.0 & 8.0 & 0.0 & 0.0 & 0.0 & 8.0 \\
\hline Trichoderma spp. & 11.0 & 3.0 & 8.0 & 8.0 & 17.0 & 10.0 & 2.0 & 0.0 & 9.0 & 0.0 \\
\hline
\end{tabular}
reduce seed quality and quantity as reported by [9], [10] and [11].

Table (1).Percentage of seed infection using standard PDA method for ten sunflower seed samples.

Based on examination of 100 sunflower seeds with the standard PDA method.

*S=Sample number

Recorded data in Table (2) show the percentage of each individual isolated fungus from sunflower seeds. The highest percentage was noticed with Aspergillus niger ( $16.5 \%)$, followed by Alternaria alternata (15.3\%) and Aspergillus flavus (13.8), respectively .On the other hand the lowest percentage was shown with Stemphylium sp.(3.1\%). The obtained results are somewhat similar to those reported by [4] and [5]. In their scientific work they reported that, the association and isolation frequencies of some fungal species isolated from sunflower seeds were clearly correlated with seeds deterioration and decay some factors may indicate the 
presence of a mixed relationships between sunflower seed-borne fungi and the extracted oil seed quality which affects on sunflower oil crop production.

Table (2). Mean percentage of seed infection using standard PDA method for each isolated fungi.

\begin{tabular}{|l|c|}
\hline Isolated fungi & $\begin{array}{c}\text { Mean } \\
\text { percentage } \\
(\%)\end{array}$ \\
\hline Aspergillus flavus & 13.8 \\
\hline Aspergillus niger & 16.5 \\
\hline Alternaria alternata & 15.3 \\
\hline Curvularia lunata & 14.0 \\
\hline Fusarium moniliforme & 9.2 \\
\hline Fusarium oxysporum & 8.2 \\
\hline Fusarium semitectum & 5.8 \\
\hline Penicillum digitatum & 7.3 \\
\hline Stemphylium sp. & 3.1 \\
\hline Trichoderma spp. & 6.8 \\
\hline
\end{tabular}

Data recorded as mean ( \% ) of ten sunflower seed samples .

Concerning the physical changes in sunflower oil due to the deterioration process of oil data in Table (3) show oil colour, absorbance (O.D.at 470nm), odor, specific gravity and moisture content. For the observance which show the (O.D. at 470nm) of deteriorated oil due to storage fungi infection the transparency of the oil are changed and varied, and there is a noticeable difference in oil absorbance (470 nm), with infection of Fusarium semitectum (0.081) and Stemphylium spp. (0.099), also, the Odor was rancid with both of them, these results may due to the secondary metabolites. The specific gravity of the tested oils is varied with Fusarium semitectum (0.308) and Stemphylium spp. (0.338).

Comparing the moisture content the highest content was 8.0 and 7.0 in case of Fusarium semitectum and Stemphylium sp., respectively. The obtained results come to other results reported by [12], [13] and [14] , they suggested that the changes in oil colour may be due to pigments synthesized by invading fungi like Aspergillus spp. Also, they reported that the extracted sunflower oils are of a great significance as a vegetarian edible oil free of high content of cholesterols and fats [13], [14].

Table ( 3 ). The Physical changes in sunflower oil due to storage fungi activity.

Table ( 3 ). The Physical changes in Sunflower oil due to storage fungi activity.
\begin{tabular}{|l|c|l|c|c|c|}
\hline Fungi & $\begin{array}{c}\text { Moisture } \\
\text { content }\end{array}$ & Oil colour & $\begin{array}{c}\text { Specific } \\
\text { gravity }\end{array}$ & $\begin{array}{c}\text { Obsorbance } \\
\mathbf{( 4 7 0} \mathbf{~ n m})\end{array}$ \\
\hline Aspergillus flavus & $* 3.0$ & Pale yellow & 0.299 & Normal & 0.113 \\
\hline Aspergillus niger & 1.0 & Yellow & 0.344 & Normal & 0.122 \\
\hline Alternaria alternata & 3.0 & Bright yellow & 0.280 & Normal & 0.114 \\
\hline Curvularia lunata & 3.0 & Yellow & 0.333 & Normal & 0.124 \\
\hline Fusarium moniliforme & 1.0 & Yellow & 0.290 & Normal & 0.111 \\
\hline Fusarium oxysporum & 4.0 & Pale yellow & 0.342 & Normal & 0.128 \\
\hline Fusarium semitectum & 8.0 & Pale yellow & 0.308 & Rancid & 0.081 \\
\hline Penicillum digitatum & 5.0 & Pale yellow & 0.289 & Specific & 0.137 \\
\hline Stemphylium sp. & 7.0 & Pale Yellow & 0.338 & Rancid & 0.099 \\
\hline Trichoderma spp. & 2.0 & Yellow & 0.296 & Normal & 0.144 \\
\hline Check & 2.0 & Yellow & 0.234 & Normal & 0.165 \\
\hline
\end{tabular}

*Data were investigated for each fungus individually relative to check treatment.

For the chemical changes as shown in Fig.(3), sunflower oils due to the deterioration process caused by storage seed-borne fungi data in Table (4), show that, the Aspergillus flavus increased the free fatty acid content (3.820) and Curvularia lunata (3.675), on the other hand, Free fatty acid content due to Alternaria alternata was decreased to $(1.512 \%)$ also, with Fusarium semitectum (1.675\%), these results are similar to those reported by [15], [16] and [17].

The highest percentage of the saponification number (s.n.) of deteriorated sunflower oils was calculated and results are summarized in Table (4) Aspergillus niger increased the s.n. to 344.02, while Curvularia lunata decreased the s.n. to 186.45.Investigating the iodine numbers show that Fusarium semitectum (150.78) and Curvularia lunata (138.49) recorded the highest iodine number, whereas other fungi results in low level like Fusarium oxysporum (100.14). Peroxide value was estimated relative to control and the highest was shown with Aspergillus flavus infection at 56 also the lowest was with Fusarium moniliforme (11), the peroxide value is an indicator of oil sample if its rancid or still stable with good quality. These results are in agreement with those reported by [17] and [18], both of rancidity and Saponification number reflects the quality of oil for its 
validity if it is stable or deteriorated and can't be consumed for human consumption as reported [15],[16], [17] and [18].

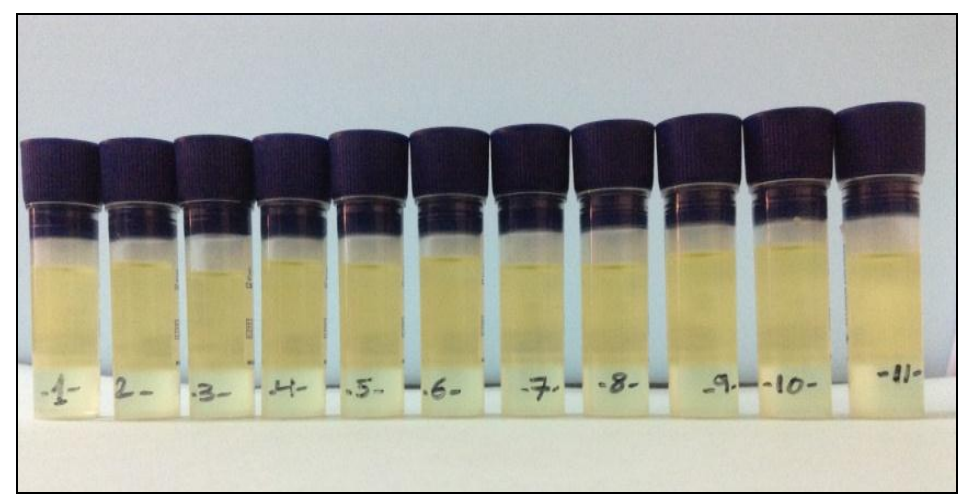

Fig. (3). The deteriorated sunflower oils for 10 samples relative to check treatment no. 11 without inoculation.

Table (4). The Chemical changes in sunflower oil due to storage fungi activity .

\begin{tabular}{|l|c|c|c|c|}
\hline Fungi & $\begin{array}{c}\text { Peroxide value } \\
(\mathbf{m E q} / \mathbf{k g})\end{array}$ & $\begin{array}{c}\text { Iodine } \\
\text { Number }\end{array}$ & $\begin{array}{c}\text { Saponification } \\
\text { Number }\end{array}$ & $\begin{array}{c}\text { Free Fatty acids } \\
(\%)\end{array}$ \\
\hline Aspergillus flavus & $* 56$ & 115.23 & 190.41 & 3.820 \\
\hline Aspergillus niger & 13 & 113.78 & 344.02 & 2.980 \\
\hline Alternaria alternata & 48 & 106.21 & 210.40 & 1.512 \\
\hline Curvularia lunata & 16 & 138.49 & 186.45 & 3.675 \\
\hline Fusarium moniliforme & 11 & 116.90 & 288.02 & 3.245 \\
\hline Fusarium oxysporum & 36 & 100.14 & 265.07 & 3.657 \\
\hline Fusarium semitectum & 17 & 150.78 & 198.54 & 1.675 \\
\hline Penicillum digitatum & 18 & 116.74 & 255.08 & 2.987 \\
\hline Stemphylium sp. & 54 & 103.32 & 223.60 & 2.346 \\
\hline Trichoderma spp. & 14 & 106.78 & 230.04 & 3.547 \\
\hline Check & 16 & 112.56 & 199.65 & 1.150 \\
\hline
\end{tabular}

*Data were investigated for each fungus individually relative to control treatment.

\section{Conclusion}

Sunflower (Helianthus annuus L.), considered a commercial oil crop all over the world, the crop is widely cultivated in Egypt and in many countries all over the world. Sunflower is particularly used for production of edible oils as well as for seed consumption. The crop is attacked by numerous seed mycoflora and these pathogens may affect the crop resulting in a reduction of the seed quantity and quality. The direct impact of storage fungi on the economical part of the plant (seed) need further studies for studying the different effects of storage fungi on sunflower oil in order to increase oil yield and crop quality for human consumption and food industries.

\section{References}

[1] Shahda W.T., Tarabeih A.M., Michail S.H., Hemeda A.A.H.( 1991). Fungi associated with sunflower seeds in Egypt with reference to chemical control measure. J. King Saud Univ. Agric. Sci. 3:287-299.

[2] Anonymous. (2007). Sunflower (Helianthus annuus L.). Pakistan Agric. Res. Council. Islamabad,Pakistan.

[3] Afzal, R.; Mughal, S. M.; Munir, M.; Sultana, K.; Qureshi, R.; Arshad, M. and Laghari, A.K. (2010).Mycoflora associated with seeds of different sunflower cultivars and its management. Pak. J.Bot., 42(1): 435-445.

[4] Godika S., Agrawal K., Sing T., (1996). Fungi associated with seeds of sunflower (Helianthus annuus L.) grown in Rajasthan and their phytopathological effects. J. Phytol. Res. 9: 61-63.

[5] Ramesh, ch. And Avitha, K. M. (2005).Presence of external and internal seed-mycoflora on sunflower seeds .J. Mycol. Pl. Pathol. 35(2):362-364.

[6] Mathur SB, Olga Kongsdul .(2003). Common Laboratory seed healthy testing methods for detecting Fungi, Danish Government Institute of Seed Pathology for Developing Countries Thorvaldsensvey57, DK- 1871. Frederiksberg C, Copenhagen, Denmark. pp. 399.

[7] Booth, C. (1971). “The Genus Fusarium”. Commonwealth Mycological Institute, Kew, Surrey, England, 237p.

[8] Abdel-Mallek, A.Y., S.S.M. El-Maraghy and H.A.H. Hasan. (1994). Mycotoxin- producing potentialities of some isolates of Aspergillus, Penicillium and Fusarium from corn grains and sunflower seeds. Assiut J. Agric. Sci., 25(2): 133-141.

[9] Prasad, T. and B. K. Singh. (1983). Effect of relative humidity on oil properties of fungal infested sunflower seeds. Bio. Bull., India. 5:85-88.

[10] Neergaard, P. (1977). Seed pathology, Vol. I and II. The Macmillan Press, London, UK. Pp. 1-1187.

[11] Abdullah S.K., Al-Mosawi K.A., (2009). Incidence of Aspergillus species in seeds of corn and sunflower cultivars grown in Iraq and aflatoxin-producing potential of Aspergillus section Flavi. Proc. $1^{\text {st }}$ Sci.Conf. Biol. Sci. Sect. Bot. Mosul Univ. Iraq: $299-307$.

[12] Ghiasian, S. A.; Kord-Bacheh, P.; Rezayat, S. M.; Maghsood, A. H. and Taherkhani, H. (2004). Mycoflora of Iranian maize harvested in the main production areas. Mycopathology. 158 (1):113-121. 
[13] Nahar, S.; M. Mushtaq and M. H. Hashmi . (2005).Seed-borne mycoflora of sunflower (Helianthus annuus L.). Pak. J. Bot., 37(2): 451-457.

[14] Kumar, G. R.; J. P. Agnihotri and A. K. Gupta. (1987). Seed Mycoflora of chickpea (Cicer arientum L.) their effect on seed germination and vigour of seedlings and their control.Indian Bot. Reptr. 6(2): 87-94.

[15] Rajendra B. Kakde and Ashok M. Chavan . (2012). Nutritional changes in soybean and safflower oil due to storage fungi. Current Botany, 3(4): 18-23.

[16] International Seed Testing Association (ISTA) .(1985). International rules for seed testing. Seed Sci. Technol. 13: 299-335.

[17] Mahajan P.D., More W.D. (1991). Fungi associated with seed in sunflower. J. Maharashtra Agric. Univ.16: $293-294$.

[18] Banu N., Muthumary J.P., (2005) .Mycobiota of sunflower seeds and samples collected from vegetable oil refinery located in Tamilnadu, India. Mycology Progress. 4: 195-204. 